УДК 330.3:339.9

Шульц С.Л., д.е.н., проф., зав. відділу регіональної економічної політики Shults S.L. Doctor of Economics, Professor http://orcid: 0000-0002-5603-5603

Луцків О.М., к.е.н., с.н.с., с.н.с. відділу регіональної економічної політики Lutskiv O.M. Candidate of Economic Sciences, Sen.Res.

http://orcid: 0000-0002-8919-6761

\title{
СТРУКТУРНА ДИВЕРСИФІКАЦІЯ ЕКОНОМІКИ ЄВРОПЕЙСЬКИХ КРАЇН ЯК ПЕРЕДУМОВА РОЗБУДОВИ ІНКЛЮЗИВНОЇ МОДЕЛІ ЇХ РОЗВИТКУ
}

\author{
ДУ «Інститут регіональних досліджень імені М.І. Долішнього НАН Украӥни»
}

У статті основну увагу зосереджено на тенденціях та особливостях структурної диверсифікації економіки європейських країн. Зазначено, що диверсифікація є не стільки метою, скільки наслідком економічного зростання і ініціюють його структурних змін, що відбуваються на основі стимульованих урядами процесів творчого руйнування з використанням інструментів сучасної структурної політики. Встановлено чинники, які впливають на диверсифікацію економіки.

Основну увагу акцентовано на зміні глобальних трендів розвитку європейських країн, а саме перехід до постіндустріального технологічного укладу, який базується на випереджаючому розвитку сфери послуг та зменшенні частки індустріального сектора (сільського господарства та промисловості у ВВП). Проаналізовано зміни в структурі економіки країн-членів ЄС упродовж 2010-2018 рр. за часткою у ВВП та зайнятості за трьома секторами економіки *первинним, вторинним та третинним). Результати аналізу свідчать, що до п’ятірки лідерів за часткою третинного сектору у ВВП увійшли Люксембург, Кіпр, Мальта, Франція та Нідерланди, а аутсайдерами у рейтингу країн за цим показником виступають Ірландія, Чехія, Румунія, Угорщина і Словенія. За часткою зайнятих в третинному секторі економіки до п'ятірки лідерів увійшла Великобританія, де 80,8\% зайнятого населення працює у сфері послуг. Здійснено аналіз структури зайнятих в розрізі галузей сфери послуг в країнах-членах $С С$ у 2018 р.

Результати аналізу свідчать, що в країнах-членах ЄС відбувається прискорений розвиток тих секторів економіки, які забезпечують значний внесок у підвищення продуктивності праці, зайнятості населення та дають змогу отримувати технологічні переваги над конкурентами. Акцентовано значну увагу на тому, шо саме кардинальна зміна технологій виробництва та активізація інноваційних процесів $\epsilon$ визначальними чинниками становлення нового технологічного укладу та забезпечують економічне зростання країн загалом.

Ключові слова: технологічні зміни, трансформації, сектори економіки, диверсифікація, економічний розвиток, інноваційні зміни, сфера послуг, постіндустріального технологічного укладу, інклюзивна модель.

\section{STRUCTURAL DIVERSIFICATION OF THE ECONOMY OF EUROPEAN COUNTRIES AS A PREREQUISITE FOR DEVELOPING AN INCLUSIVE MODEL OF THEIR DEVELOPMENT}

\author{
SI "The Institute of Regional Research named after M.I. Dolishniy of the NAS of Ukraine”
}

The article focuses on the trends and features of structural diversification of the economy of European countries. It is noted that diversification is not so much a goal as a consequence of economic growth and its initiating structural changes, which occur on the basis of government-stimulated processes of creative destruction using the tools of modern structural policy.

The main focus is on changing global development trends in European countries, namely the transition to a post-industrial technological structure, which is based on the advanced development of services and reducing the share of the industrial sector (agriculture and industry in GDP). The changes in the structure of the economy of the EU member states during 2010-2018 by the share in GDP and employment by three sectors of the economy (primary, secondary and tertiary) are analyzed. The analysis shows that Luxembourg, Cyprus, Malta, France and the Netherlands are in the top five in terms of the share of the tertiary sector in GDP, while Ireland, the Czech Republic, Romania, Hungary and Slovenia are outsiders in the ranking of countries. In terms of the share of those employed in the tertiary sector of the economy, the top five included the United Kingdom, where $80.8 \%$ of the employed population works in services. An analysis of the structure of employment in the service sector in the EU member states in 2018. 
The results of the analysis show that in the EU member states there is an accelerated development of those sectors of the economy that provide a significant contribution to increasing labor productivity, employment and allow to gain technological advantages over competitors. Emphasis is placed on the fact that a radical change in production technologies and the intensification of innovation processes are the determining factors in the formation of a new technological structure and ensure economic growth in general.

Keywords: technological changes, transformations, economic sectors, diversification, economic development, innovative changes, services, post-industrial technological structure, inclusive model.

Постановка проблеми у загальному вигляді з її важливими науковими та практичними завданнями. Визначальною ознакою сучасного розвитку європейських країн $є$ надзвичайно швидкі трансформаційні процеси зумовлені технологічними інноваціями та розвитком цифрової економіки. Економіка більшості країн світу в умовах глобалізації є залежною не лише від внутрішньої динаміки, але й від структурних змін у світовій економіці. На сьогодні глобальним трендом розвитку європейських країн $\epsilon$ перехід до постіндустріального технологічного укладу, який базується на випереджаючому розвиток т.зв. третинного сектора - сектора послуг та зменшенні частки індустріального. Неминучість переходу до нового технологічного укладу ставить країни світу перед новими викликами - розробляти та впроваджувати нові технології та долучитися до нових трендів економічного розвитку, або залишатись країні на сьогоднішньому етапі економічного розвитку, що у свою чергу приведе до зниження їх конкурентоспроможності на світовому ринку. Саме формування ефективної структури економіки $є$ основою макроекономічної стабілізації країни та економічного зростання загалом. Сьогодні структурна диверсифікація економіки має бути спрямована на розширення розробки конкурентоспроможних інноваційних технологій та випуску споживачам необхідного обсягу інноваційної продукції і формування інклюзивної моделі економічного розвитку.

Аналіз останніх досліджень, у яких започатковано вирішення проблеми. Дослідження проблеми трансформаційних перетворень в країнах знайшли своє відображення в працях, як зарубіжних так і вітчизняних вчених. Серед них слід відзначити работи С. Брю, 3. Варналія, А. Гальчинського, В. Гейця, С. Глазьева [1], Гриценка, Г. Доси [2], Я. Жаліла, І. Лукінова [3], Г. Менша, В. Полтеровича, С. Розефілда, М. Фрідмена, П. Хансона, С. Хедлунда, Й. Шумпетера та інших. Однак, не зважаючи на значний інтерес до вивчення цієї проблематики багато питань пов'язаних 3 дослідженням процесів ринкової трансформації на регіональному рівні, впливу структурних чинників на процеси економічного розвитку, окремих аспектів трансформації інноваційних процесів та інноваційних систем і надалі залишаються мало дослідженими та потребують пошуку шляхів їх подальшого дослідження.

Мета статті полягає у дослідженні сучасних тенденцій структурної диверсифікації економіки європейських країн як основи розбудови інклюзивної моделі розвитку їх економіки.

Виклад основного матеріалу дослідження 3 повним обгрунтуванням отриманих наукових результатів. Інклюзивний розвиток визначено одним із ключових пріоритетів у стратегії економічного зростання «Європа-2020». Основними орієнтирами інклюзивної моделі розвитку європейських країн $\epsilon$ підтримка освіти, досліджень та інновацій, які саме забезпечують створення нових робочих місця, тобто допомагають у вирішенні соціальних проблем та забезпечують економічне зростання загалом. На сьогодні, важливу роль в процесах економічного зростання європейських краї відіграють інклюзивні інновації. Слід зазначити, що інклюзивні інновації, це інновації створені для різних груп населення й передбачають залученість виробників у створення інноваційних продуктів і технологій з врахуванням особливостей ринків бідних країн. Світовий банк вкладає в поняття «інклюзивні інновації» «створення знань і зусилля щодо їхньої реалізації у вигляді продуктів і послуг, які найбільш актуальні для потреб бідних». Ключовим питанням для розвитку та поширення інклюзивних інновацій є створення відповідних інклюзивних економічних інститутів, які сприяють і заохочують участь 
великих мас людей у різних видах економічної діяльності, які приносять найкраще використання їхніх талантів і майстерності й надають можливість індивідам робити той вибір, який вони бажають. [4].

Диверсифікація є не стільки метою, скільки наслідком економічного зростання і ініціюють його структурних змін, що відбуваються на основі стимульованих урядами процесів творчого руйнування 3 використанням інструментів сучасної структурної політики. В загальному вигляді диверсифікацією структури економіки розглядають, як засіб забезпечення досягнення динамічного соціально-економічного розвитку країни. Тобто при дослідженні диверсифікації розглядаються питання взаємозв'язку між зміною секторальної й галузевої структури економіки та ефективністю економіки.

Перехід економіки країн на V i VI технологічні уклади передбачає пріоритетність розвитку сфери послуг та інформаційних технологій. Тому глобальною закономірністю змін у секторально-галузевій структурі світової економіки, яка відбуваються протягом кількох останніх десятиліть слід вважати поступове зменшення частки сільського господарства та промисловості у ВВП та одночасне збільшення частки сфери послуг. Тобто загальною тенденцією диверсифікації структури економіки європейських країн $є$ пріоритетність розвитку сфери послуг, Цю тенденцію спостерігаємо у країнах-членах $€ С$, де частка третинного сектора у ВВП є домінуючою (рис.1).

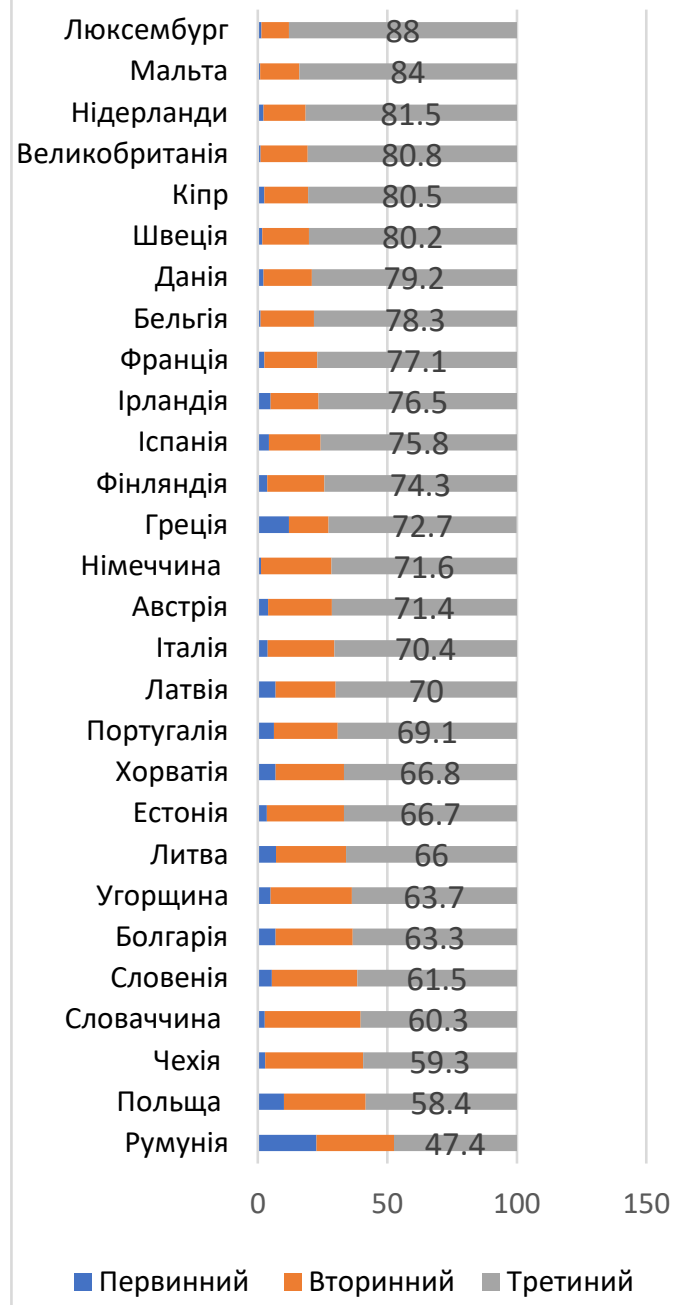

a) за часткою у ВВП

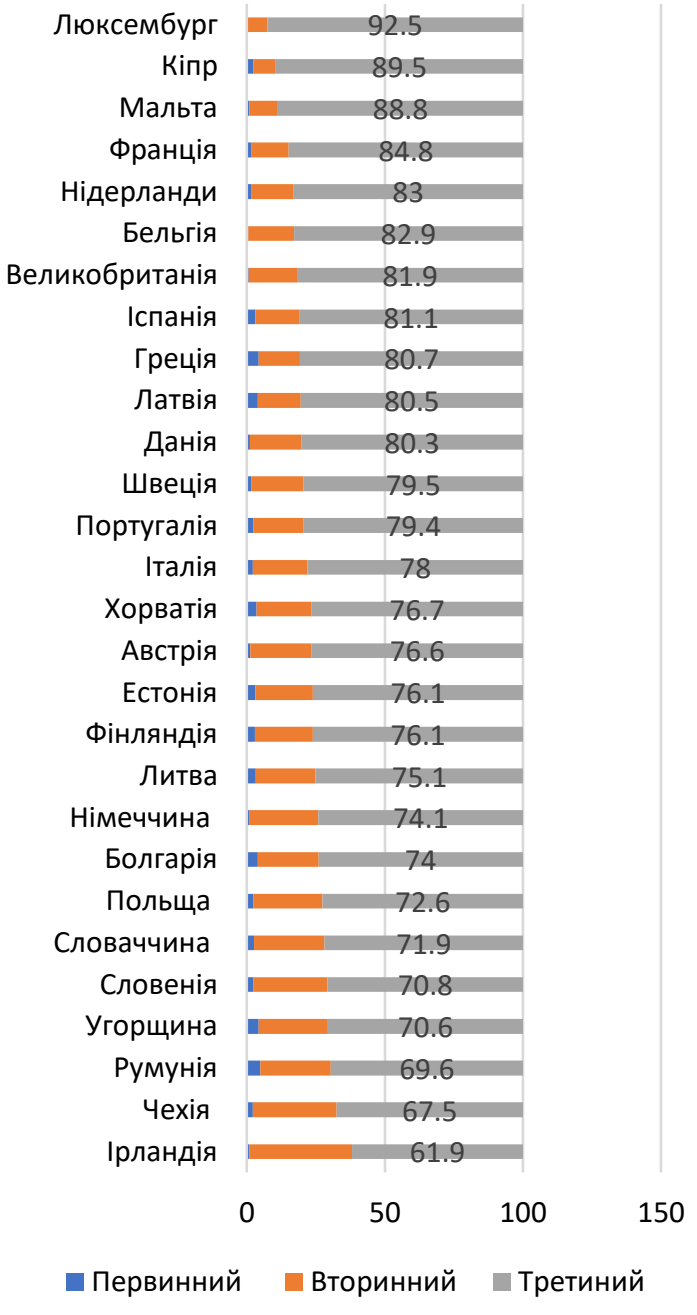

б) за часткою зайнятих

Рис. 1. Секторальна структура економіки країн-членів СС, 2018p.

*Розраховано за даними: [5] 
До п’ятірки лідерів за часткою третинного сектору у ВВП увійшли Люксембург, Кіпр, Мальта, Франція та Нідерланди, а аутсайдерами у рейтингу країн за цим показником виступають Ірландія, Чехія, Румунія, Угорщина і Словенія. За часткою зайнятих в третинному секторі економіки до п’ятірки лідерів увійшла Великобританія, де $80,8 \%$ зайнятого населення працює у сфері послуг [5].

Аналізуючи зміни в структурі економіки країн-членів СС упродовж 2010-2018 pp. спостерігаємо зростання частки первинного сектору у ВВП країн Східної Свропи зокрема, Чехії, Словаччини, Угорщини і Чехії, а також Греції (рис. 2). Суттєве зменшення частки галузей вторинного сектору у ВВП фіксуємо в Румунії, а іiі значне зростання в Ірландії. Такі зміни відбулись внаслідок перенесення в Ірландію штабквартир великих корпорацій промисловості та активізацію розвитку будівництва, що загалом призвело до зростання ВВП країни та покращення інших макроекономічних показників. Динаміку розвитку третинного сектору за показником частки в структурі ВВП характеризує його зростання майже в усіх країнах-членах ЄС.

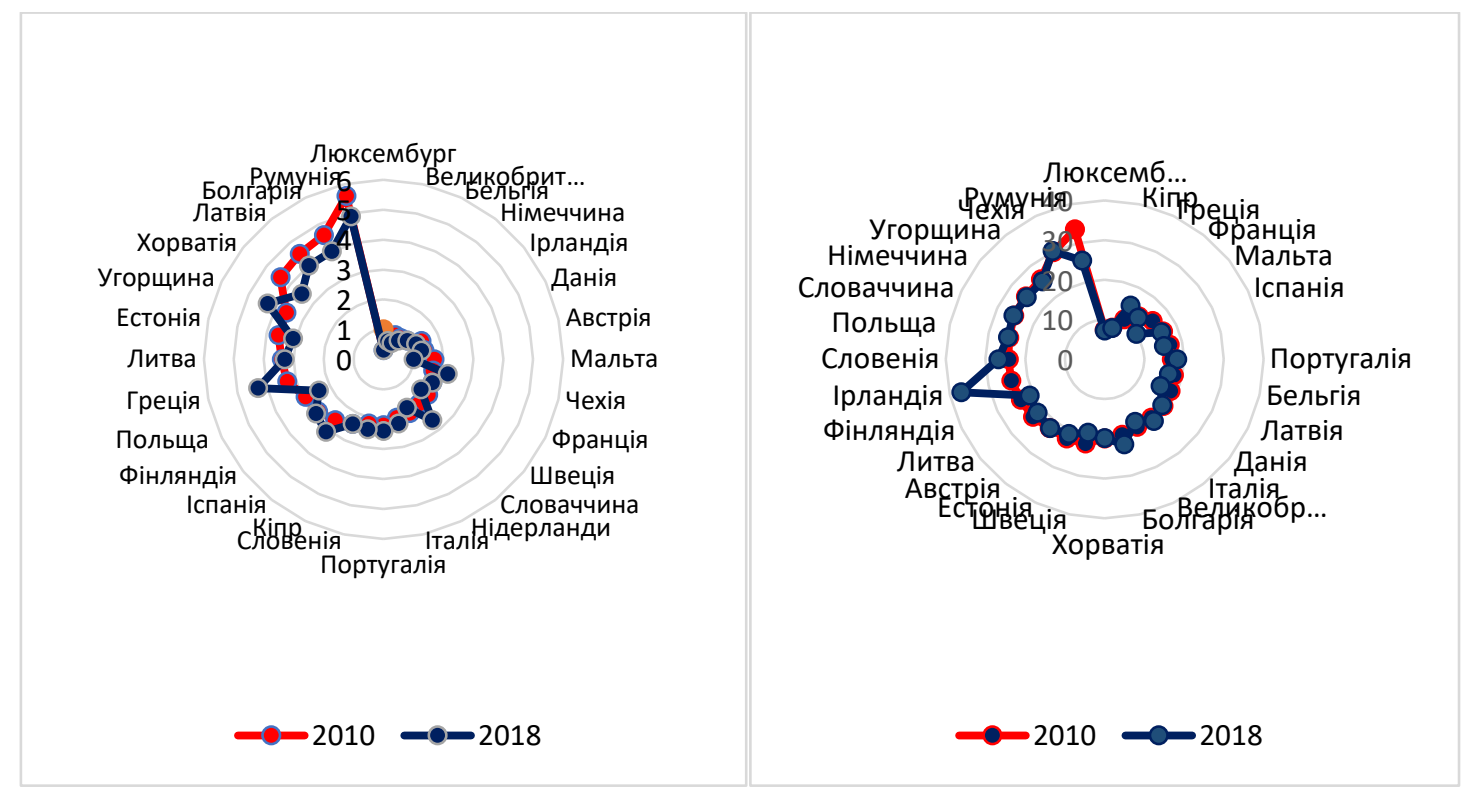
А) Первинний сектор
Б) Вторинний сектор

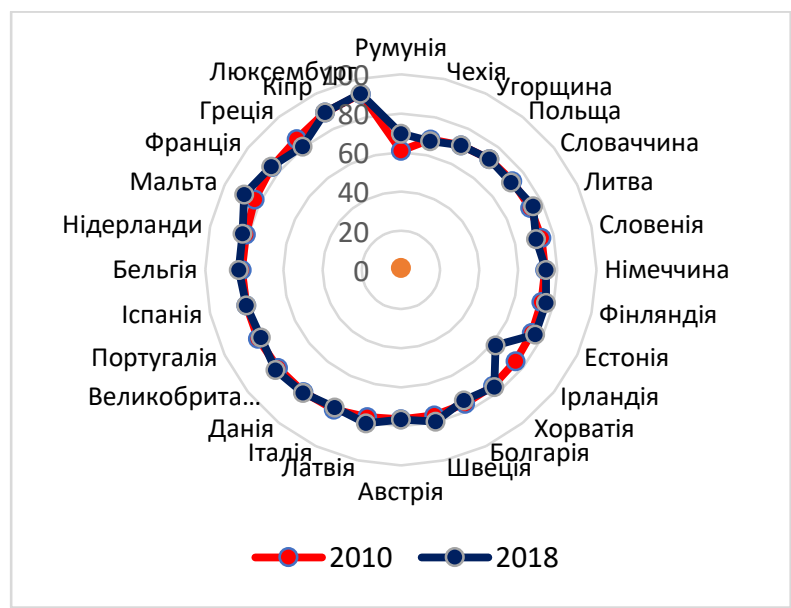

В) Териттнний сектор

Рис. 2. Динаміка частки секторів економіки у ВВП країн-членів ЕС (за часткою у ВВП), у 2010 та 2018 p.

*Розраховано за даними: [5] 
На тлі прискореного розвитку сектору послуг у всіх групах розвинутих країн спостерігався стійкий, хоча й помірний в кількісному виразі тренд відносного зменшення ролі індустріального сектору. Навіть у групі країн, що розвиваються, зростання промисловості стримується наявною в ній відносно більш високою, ніж у середньому по економіці, продуктивністю. Фактично сьогодні світовим лідером за розміром частки обробної промисловості у структурі ВВП $є$ найменш розвинуті країни світу $(24,3 \%$ у 2016р.). Саме пришвидшений розвиток третинного сектору економіки $є$ запорукою інклюзивної моделі розвитку європейських країн.

Структурні зміни в економіці країн-членів СС засвідчують наступні тенденції. В країнах, які приєднались до Євросоюзу після 2004 року частка населення, зайнятого у сільському господарстві у 2019 році була вищою, і коливалась від 22,61\% (Румунія) до 1\% (Мальта) і 1,15\% (Великобританія, Бельгія) при середньому її значенні по СС 4,9%. Натомість у промисловості найбільша частка зайнятих працює в країнах постсоціалістичного простору, зокрема у Чехії (37,86\%), Словаччині (36,96\%), Словенії (32,86\%), Польщі (31,34\%), Угорщині (31,17\%) (рис. 3) [5].

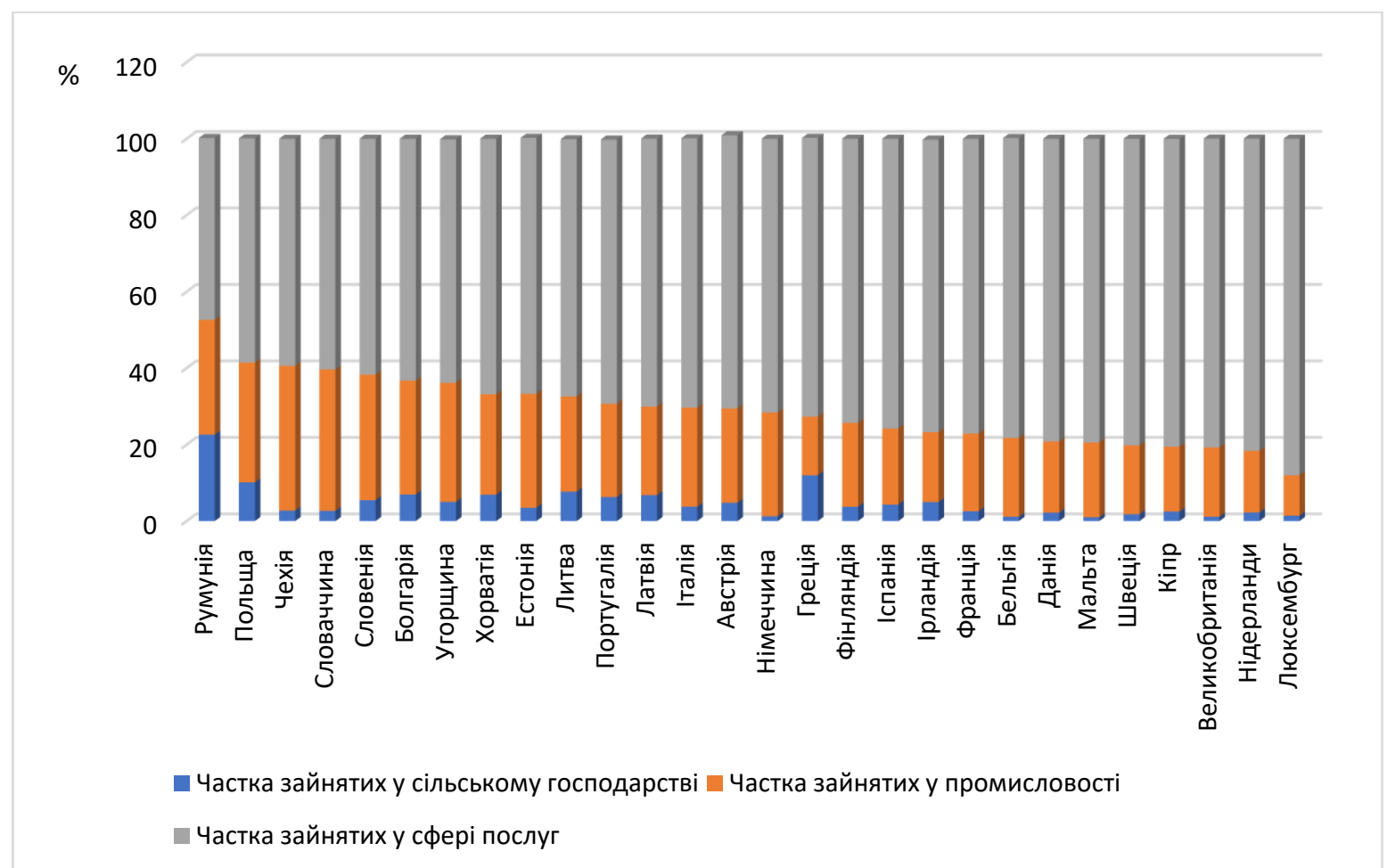

Рис. 3. Частка зайнятих у сільському господарстві, промисловості та сфері послуг, на $1.01 .2020 \mathrm{p}$.

*Розраховано за даними: [5]

Найнижча частка зайнятих у промисловості характерна для Люксембурга $(10,57 \%)$ та Греції (15\%). Середня частка зайнятих у сфері послуг у країнах ЄС сягає $71,1 \%$, а лідерами за цим показником є Люксембург (88,5\%) та Великобританія $(80,75 \%)$ (див. рис. 3). 


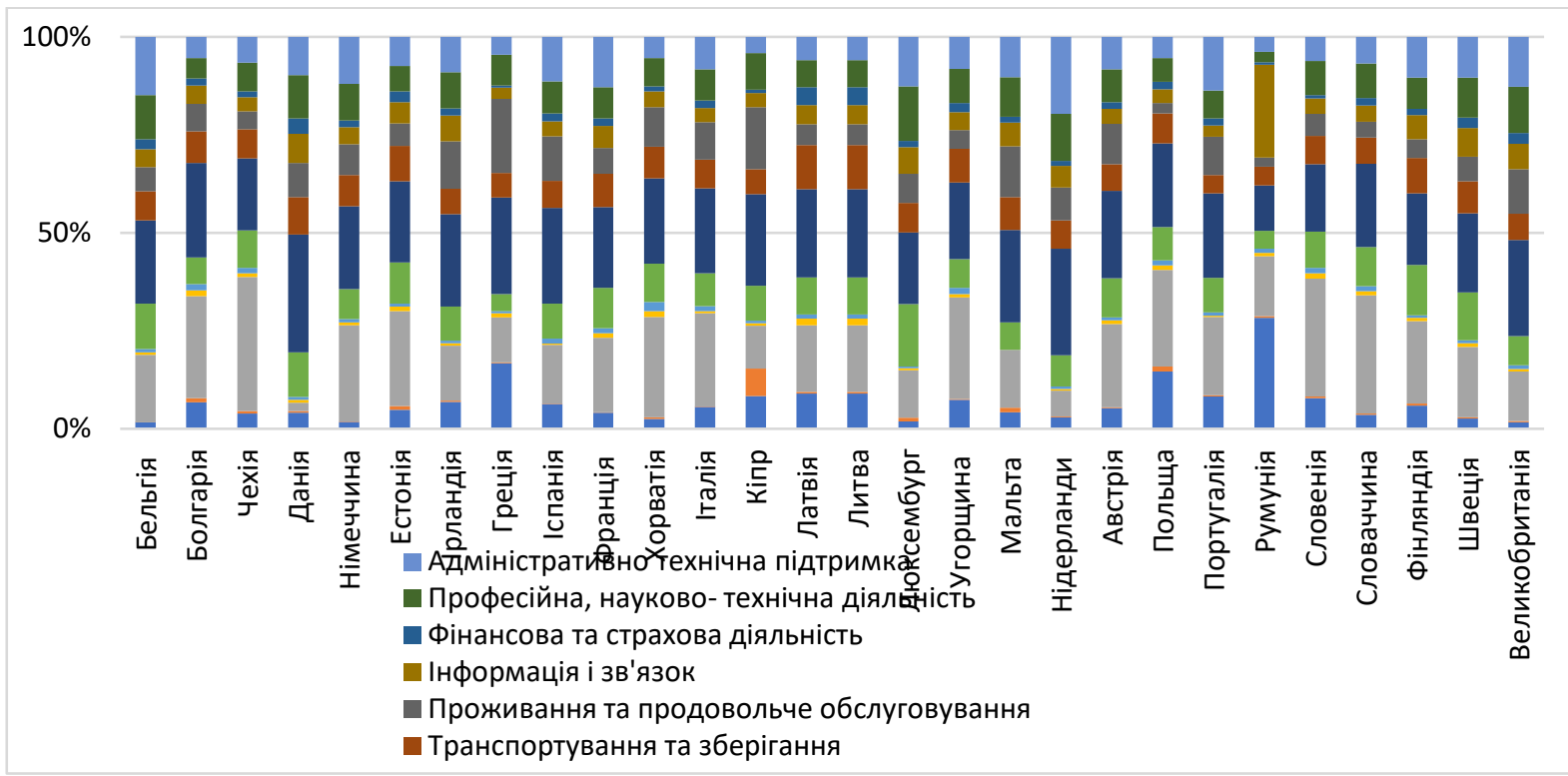

NACE Rev. 2)

*Розраховано за даними: [5]

Сьогодні в країнах-членах ЄС спостерігаємо високі показники кількості зайнятих у оптовій та роздрібній торгівлі, де серед лідерів за часткою зайнятих Данія $(30,2 \%)$, Нідерланди (27,1\%), Греція (24,6\%) та Великобританія $(24,5 \%)$. Середня частка зайнятих у фінансовій та страховій діяльності в країнах-членах ЄС складає лише $2 \%$, проте в сфері професійної та науково-технічної діяльності сягає 8,5\%. Найвищою питомою вагою працівників цього виду діяльності у загальній структурі зайнятого населення вирізняються Люксембург (14\%), Нідерланди (12\%) і Великобританія (11,9\%) (рис.4) [5].

Отже, в країнах-членах $\mathrm{CC}$ фіксують прискорений розвиток тих секторів економіки, які, 3 одного боку, забезпечують значний внесок у підвищення продуктивності праці, зайнятості населення, а 3 іншого - дають змогу отримувати технологічні переваги над конкурентами. Принципова зміна технологій виробництва та активність щодо впровадження інновацій є визначальними чинниками і драйверами становлення нового технологічного укладу та формування траєкторії зростання економіки країн загалом. Саме в країнах з високим рівнем інноваційного розвитку розвиваються високотехнологічні галузі, формується технологічний каркас нового технологічного укладу.

Висновок. Підсумовуючи вище наведене слід зазначити, що загальним напрямком структурних змін у світовій економіці в останні десятиліття є тренд до зростання частки сфери послуг. IIÏ активна роль у формуванні процесів економічного розвитку задає інклюзивні напрями структурної еволюції світової економіки, які базується на трьох основоположних критеріях: науці, освіті та інноваціях. Саме інклюзивні інноваційні технології відіграють ключову роль в економічному розвитку й призводять до кардинальних змін у структурі економічної діяльності через запровадження у ринковий простір нових технологій виробництва, які мають змогу задовольняти існуючі потреби і створювати нові можливості для появи принципово нових потреб суспільства та економічного зростання загалом.

\section{Список бібліографічного опису}

1.Глазьев С.Ю. Теория долгосрочного технико-экономического развития. М.: ВлаДар. 1993. С. 61-62.

2.Dosi G. Technological Paradigms and Technological Trajectories: A Suggested Interpretation of the Determinants and Directions of Technical Change. Research Policy. Volume 11. Issue 3. 1982. P. 147-162.

3.Лукінов I.I. Економічні трансформації (наприкінці XX сторіччя). - К. Книга. 1977. 456 с. 
4.Dutz M.A. Unleashing India’ s Innovation: Toward Sustainable and Inclusive Growth. Washington, DC: World Bank. 2007. URL: https://openknowledge.worldbank.org/handle/10986/6856 License: CC BY 3.0 IGO.”

5.Eurostast. URL: https://ec.europa.eu/eurostat/

\section{References}

1.Glaz’ev S.Yu. (1993). Teory`ya dolgosrochnogo texny`ko-ekonomy`cheskogo razvy`ty ya [Theory of long-term technical and economic development]. M.: VlaDar. [in Russia]

2.Dosi G. (1982) Technological Paradigms and Technological Trajectories: A Suggested Interpretation of the Determinants and Directions of Technical Change. Research Policy. Volume 11. Issue 3. [in English].

3.Lukinov, I. (1997). Ekonomichni transformacii (naprykintsi XX storichchya) [Economic transformations (late 20th century)]. Kiev: Kniga [in Ukrainian].

4.Dutz M.A. (2007). Unleashing India' s Innovation: Toward Sustainable and Inclusive Growth. Washington, DC: World Bank.. Retrieved from https://openknowledge.worldbank.org/handle/10986/6856 License: CC BY 3.0 IGO." [in English].

5.Eurostast. Retrieved from https://ec.europa.eu/eurostat/ [in English].

Дата подання публікації 15.06.2020 р. 